\title{
The Physiology of Heat Stress: A Shift in Metabolic Priorities at the Systemic and Cellular Levels
}

\author{
Robert P. Rhoads ${ }^{1}$, Lance H. Baumgard ${ }^{2}$ and Lidan Zhao ${ }^{3}$
}

\begin{abstract}
At the onset of heat stress, cattle initiate a series of whole body adaptations in an effort to cope with and dissipate additional heat load. These include well-known physiological changes such as increased respiration rate and sweating rate and decreased feed intake. Environmentally induced hyperthermia in ruminants depresses production as a consequence of reduced feed intake but it is unclear how shifts in metabolism may further affect production performance and physiological acclimation. Our evidence indicates that cattle experiencing heat stress do not appear to engage metabolic and glucose-sparing adaptations consistent with their plane of nutrition. In this context, the liver is uniquely positioned to direct exogenously and endogenously derived nutrients for use by other metabolically active tissues such as the mammary gland and skeletal muscle. Despite the prominent role of the liver in whole-body metabolism, alterations in the molecular mechanisms leading to hepatic adaptation during heat challenge are unclear. We are using management tools and metabolic modifiers, such as bovine somatotropin, in an attempt to better understand and improve hepatic function during heat stress. Because a large proportion of an animal's mass is comprised of skeletal muscle, alterations in skeletal muscle metabolism and function can have a profound impact on whole-animal energy metabolism and nutrient homeostasis especially during periods of stress. We have initiated studies to understand how hyperthermia influences the set points of several metabolic pathways within skeletal muscle. It appears that during heat stress bovine skeletal muscle experiences mitochondrial dysfunction leading to impaired cellular energy status. Finally, investigations into adipose tissue metabolism demonstrate impaired lipolytic functions likely due to a refractory nature to adrenergic stimuli. Taken together, this may have broad implications for the reduced production and heat intolerance seen during heat stress especially if tissue(s) are not able to make necessary contributions to whole-body energy homeostasis. Accurately understanding the biological mechanism(s) by which thermal stress reduces animal performance is critical for developing novel approaches (i.e. genetic, managerial and nutritional) to preserve growth and lactation especially given the critical importance of nutrients, such as glucose, to animal production and well being in these situations.
\end{abstract}

Keywords: Heat load, metabolism, metabolic modifiers, sweating rate.

\section{La Fisiología del Estrés: Un Cambio de Prioridades Metabólicas a Nivel Sistémico y Celular}

Resumen. Al iniciarse el estrés calórico, el ganado inicia una serie de adaptaciones en un esfuerzo de lidiar y disipar la carga adicional de calor, estos incluyen cambios fisiológicos muy conocidos como el incremento de la respiración y la sudoración, y una disminución de la ingesta. La hipertermia inducida por el ambiente en rumiantes reduce la producción como consecuencia de la reducción en la ingesta, pero no está claro como los cambios en el metabolismo pueden afectar la producción y la aclimatación fisiológica. Nuestra evidencia indica que el ganado que experimenta estrés calórico no parece participar en adaptaciones metabólicas y de preservación de glucosa consistentes con su nivel de nutrición. En este contexto, el hígado puede dirigir los nutrientes derivados de forma exógena y endógena para su uso por otros tejidos que son metabólicamente activos como la glándula mamaria y el músculo esquelético. A pesar de la función prominente del hígado en el metabolismo, las alteraciones en los mecanismos moleculares que conllevan a adaptaciones hepáticas durante el estrés calórico aún no están claras. Se están usando herramientas de manejo y modificadores metabólicos, como la somatotropina bovina, en un intento de mejorar nuestro entendimiento y mejorar la función hepática durante el estrés calórico. Ya que una

\footnotetext{
${ }^{1}$ Virginia Tech University, Dept. of Animal and Poultry Sciences, 3080 Litton-Reaves Hall, Blacksburg, Virginia, United States, 24061. Email: rhoadsr@vt.edu.

${ }^{2}$ lowa State University, Dept. of Animal Science, 313J Kildee Hall, Ames, lowa, United States, 50011. Email: baumgard@iastate.edu.

${ }^{3}$ Virginia Tech University, Dept. of Animal and Poultry Sciences, 3110 Litton-Reaves Hall, Blacksburg, Virginia, United States, 24061. Email: lidan@vt.edu.
} 
gran proporción de la masa del animal está compuesta por el músculo esquelético, las alteraciones en el metabolismo y función del mismo pueden tener impactos profundos en el metabolismo del animal y la homeostasis de nutrientes especialmente durante períodos de estrés. Hemos iniciado estudios para entender como la hipertermia influencia ciertos puntos de varias vías metabólicas dentro del músculo esquelético. Todo indica que durante el estrés calórico el músculo esquelético bovino sufre una disfunción mitocondrial que lleva a un estatus celular alterado. Finalmente, la investigación con el metabolismo del tejido adiposo demuestra funciones lipolíticas alteradas debido al carácter refractario de los estímulos adrenérgicos. En conjunto, esto puede llevar a implicaciones amplias para la producción disminuida y la intolerancia al calor que se observa durante el estrés calórico si los tejidos no son capaces de contribuir a la homeostasis del organismo. Poder entender con exactitud el mecanismo biológico por el cual el estrés calórico reduce el rendimiento del animal es crítico para desarrollar nuevas tácticas (i.e. genética, manejo y nutrición) para preservar el crecimiento y la lactancia, especialmente dada la importancia crítica de los nutrientes como la glucosa, para la producción animal y el bienestar en estas situaciones.

Palabras clave: Carga térmica, metabolismo, modificadores metabólicos, tasa de transpiración.

\section{Introduction}

The physiological effects of heat stress on the productivity of cattle are financially devastating for the agricultural industries. These physiological and nutritional effects are the subject of excellent reviews by Beede and Collier (1986), Baumgard and Rhoads (2013) and Rhoads et al. (2013). During periods of heat stress, dry matter intake (DMI) decreases and maintenance requirements increase as cattle attempt to dissipate excess heat load (West 1999). In addition, changes in blood flow and the production of various hormones may result in decreased milk production, reproductive performance and growth: economically vital aspects of beef and dairy production. The biological mechanisms that mediate these effects, however, are not completely understood. In general, heat stress induced production losses for beef cattle are not as severe as those for the dairy industry. Negative effects of heat stress are especially apparent in animal agriculture, as collectively these effects are estimated to cost United States animal agri-business approximately $\$ 2$ billion annually. The dairy industry alone accounts for nearly $\$ 1$ billion in economic losses due to heat stress (St-Pierre et al. 2003). Despite beef cattle's increased heat tolerance compared to high producing dairy cattle, the economic impact is significant and costs the American beef industry hundreds of millions of dollars (St-Pierre et al. 2003). In this discussion, the focus will be on factors we are investigating that affect performance during periods of heat stress: changes in skeletal muscle metabolism and possible implications on growth and lactation.

\section{Metabolic Adaptations to Heat Stress}

The biological mechanism by which heat stress impacts production and reproduction is partly explained by reduced feed intake, but also includes altered endocrine status, reduction in rumination and nutrient absorption, and increased maintenance requirements (Collier and Beede, 1985; Collier et al. 2006) resulting in a net decrease in nutrient/energy available for production. Heat stress research in animal production has previously concentrated on environmental/dietary modification and physiological changes, which occur during thermal challenges (Collier et al. 2006). Increases in rectal temperatures and respiration rates with concomitant decreases in DMI as well as milk production are repeatedly documented in heat stress research (Collier et al. 1982; McGuire et al. 1989; 1991; Elvinger et al. 1992). However, understanding nutrient partitioning and the alterations in metabolism is necessary to combat these effects.

By comparing the temporal patterns of milk yield and DMI during a thermal load, it is clear heat stress has both direct and indirect effects on cattle. For example, Shwartz and colleagues (2009) discovered discordant temporal patterns in milk yield and DMI from HS cows. Specifically, milk yield decreased approximately $33 \%$ and stabilized (by the third week) while DMI improved in the third week of heat stress after decreasing $29 \%$ from the thermal neutral period. In a subsequent study, Rhoads and colleagues (2009) used a basic pair-feeding (PF) model (a second group of cattle housed in thermal neutral conditions fed to the level of the heat-stressed cows) to eliminate 
confounding effects of dissimilar feed intakes (separating the direct effects of heat stress from the indirect effects of lower feed intake on metabolism). As designed, both the HS and PF cattle reduced DMI by $37 \%$ while milk yield decreased $41 \%$ in HS cows compared to only $21 \%$ in PF cows. Therefore, it is clear that reduced nutrient intake only accounts for approximately $35 \%$ of the decreased milk production.

Cattle typically initiate glucose-sparing mechanisms (i.e. mobilize adipose tissue) while in NEBAL. In other words, adipose tissue mobilization (lipolysis) increases and adipose derived NEFA become the primary systemic fuel source (Bauman et al. 1988). However, plasma NEFA concentrations did not increase in HS cows (Rhoads et al. 2009; Shwartz et al. 2009; Wheelock et al. 2010) while PF cows had a typical rise in circulating NEFA concentrations. Not only were basal NEFA suppressed, but adipose responsiveness to an adrenergic stimulus was also blunted in HS cows (Wheelock et al. 2010). This suggests cows experiencing a thermal load reprioritize fuel-selection in favor of glucose, also evident by HS cows having decreased plasma glucose concentrations (Rhoads et al. 2009; Shwartz et al. 2009; Wheelock et al. 2010). Lower concentrations of glucose can be explained by higher plasma concentrations of insulin, frequently observed in HS dairy cows (Wheelock et al. 2010).

Insulin appears to be a primary element towards understanding the metabolic changes occurring during HS. During a glucose tolerance test (GTT), glucose disposal increased as demonstrated by a smaller area under the curve (AUC) response in HS compared to PF cows. Increased pancreatic sensitivity (enhanced insulin response) to glucose was also apparent in HS cows (Wheelock et al. 2010). An insulin tolerance test (ITT) provides an estimate of tissue sensitivity to insulin. Heat-stressed cows appear to remain sensitive to insulin at peripheral tissues, as indicated by the similar glucose clearances as well as decreased NEFA levels (Wheelock et al. 2010). These metabolic responses suggest that while typical underfed dairy cows become insulin insensitive, HS cows remain insulin responsive, which allows for the use and uptake of glucose. Similar to lactating dairy cows, heatstressed growing bulls appear to have an increase in glucose disposal rates and have a much greater insulin response to a glucose challenge (O'Brien et al. 2010). As a consequence, heat-stressed cattle may become increasingly dependant on glucose for energetic needs and less reliant or able to use other energetic substrates.

\section{Heat Stress and Liver Metabolism}

Heat-stressed athletes consistently have increased hepatic glucose production and whole body enhanced carbohydrate oxidation at the expense of lipids (Fink et al. 1975; Febbraio, 2001; Jentjens et al. 2002). Moreover, even consumption of exogenous carbohydrates are unable to blunt the HS-induced liver glucose output (Angus et al. 2001). The increased hepatic glucose output originates from increased glycogenolysis (Febbraio, 2001) and increased gluconeogenesis (Collins et al. 1980). Hepatic pyruvate carboxylase gene expression, a rate-limiting gluconeogenic enzyme controlling lactate and alanine entry into the gluconeogenic pathway, is consistently increased during $\mathrm{HS}$ in multiple animal models (Wheelock et al. 2008; O'Brien et al. 2010; Rhoads et al. 2011). Interestingly, numerous studies indicate plasma lactate concentrations rise during exercise in the heat (Rowell et al. 1968; Fink et al. 1975; Angus et al. 2001), porcine malignant hyperthermia (Hall et al. 1980), and heat-stressed growing steers (O'Brien et al. 2010), presumably stemming from skeletal muscle efflux. Taken together, these studies point to increased anaerobic glycolysis in peripheral tissues and the Cori cycle may be a key mechanism to maintain glucose and energy homeostasis.

Somatotropin and insulin-like growth factor I (IGF-I) are two of the most potent and well-characterized lactogenic hormones (Rhoads et al. 2004). Normally, somatotropin partitions nutrients towards the mammary gland by decreasing nutrient uptake by extra-mammary tissues and stimulating hepatic IGF-I synthesis and secretion. During NEBAL (i.e. early lactation), the somatotropic axis uncouples and hepatic IGF-I production decreases despite increased circulating somatotropin concentrations (McGuire et al. 1992). We originally hypothesized that NEBAL caused by HS and early lactation differentially affects the somatotropic axis. To evaluate this further, we analyzed basal somatotropin pulsatility characteristics and the pituitary's responsiveness to a somatotropin secretagogue and reported no differences in either parameter in HS versus pair-fed thermal neutral controls (Rhoads et al. 2009). However, we did measure a modest reduction in circulating IGF-I, which may indicate the metabolic milieu favors uncoupling of 
the somatotropic axis during HS (Rhoads et al. 2009). We investigated whether hepatic growth hormone (GH)-responsiveness was altered during HS by measuring $\mathrm{GH}$ receptor abundance and signal transducer and activator of transcription 5 (STAT-5) phosphorylation (Rhoads et al. 2010). Heat stress, independent of reduced feed intake, decreased hepatic $\mathrm{GH}$ receptor abundance although both $\mathrm{HS}$ and malnutrition were sufficient to decrease STAT-5 phosphorylation. Consistent with reduced $\mathrm{GH}$ signalling through STAT-5, hepatic IGF-I mRNA abundance was lower in heat-stressed animals. Thus, the reduced hepatic GH responsiveness observed during HS appears to involve mechanisms independent of reduced feed intake. The physiological significance of reduced hepatic $\mathrm{GH}$ receptor abundance during $\mathrm{HS}$ is unclear at this time but may serve to alter other $\mathrm{GH}$ dependent hepatic processes such as gluconeogenesis regulation.

\section{Heat Stress and Adipose Tissue Metabolism}

During food deprivation, or the times when animals enter negative energy balance (e.g. early lactation), lipid reserves are mobilized and starting to release FA in a reverse manner of esterification carried out by a set of lipase. A monolayer membrane and membrane proteins protect the lipid droplet. Perilipin A is a predominant isoform of perilipin that locates at lipid droplet membrane and regulates the basal and stimulated lipolysis (Duncan et al. 2007; Brasaemle et al. 2009). When a catabolic signal is received by adipocyte, perilipin $A$ is phosphorylated and triggers the release of CGI-58, a coactivator of adipose triglyceride lipase (ATGL). The three acyl groups are hydrolyzed successively by ATGL, hormone sensitive lipase (HSL), and monoacylglycerol lipase (Farese and Walther, 2009). Liberated FA with 14 carbons or more has to be activated in the form of acyl-CoA by long chain acyl-CoA synthetase and transported into mitochondria through the carnitine shuttle with the aid of carnitine palmitoyltransferase (CPT) -I, carnitine:acylcarnitine translocase, and CPT-II (Kerner and Hoppel, 2000; Nguyen et al. 2008). Acyl-CoA translocated in mitochondria undergoes a process called $\beta$-oxidation catalyzed by enzymes following a 4step cycle, releasing one acetyl-CoA each cycle (Wanders et al. 2010). $\beta$-oxidation also generates reducing equivalent: reduced form of flavin adenine dinucleotide (FADH) and nicotinamide adenine dinucleotide $(\mathrm{NADH})$ as end products (Nguyen et al.
2008). Acetyl-CoA can enter the tricarboxylic (TCA) cycle to produce ATP. If large amount of FA is released in the blood stream, such as fasting, under catecholaminergic stress, or after the consumption of high-fat, low-carbohydrate diet, FA taken up by liver can undergo a pathway called ketogenesis to generate ketone bodies, which can be utilized by brain, kidney and muscle as fuel (Fukao et al. 2004). Acetyl-CoA produced from $\beta$-oxidation accumulates in mitochondria and becomes the substrate of generating ketone bodies, which are transported to extrahepatic tissues to go through ketolysis, a reverse set of reaction of ketogenesis, and ketone bodies are converted back to acetyl-CoA in those tissues to enter TCA cycle (Fukao et al. 2004).

Production data suggests HS may alter lipid metabolism differently than would be expected based upon calculated whole body energy balance. For example, HS sows (Prunier et al. 1997) and heifers (Ronchi et al. 1999) do not lose as much body weight and body condition, respectively, as do their pair-fed thermal neutral (PFTN) counterparts. In addition, carcass data indicates that rodents, chickens and pigs have increased lipid retention when reared in HS conditions. We and others have demonstrated that basal plasma NEFA levels (a product of adipose lipolysis and mobilization) are typically reduced in HS rodents, sheep and cattle despite marked reductions in feed intake (Sano et al. 1983; Ronchi et al. 1999; Shwartz et al. 2009), and especially when compared to PFTN controls (Rhoads et al. 2009). Furthermore, heat-stressed cows have a blunted (compared to PFTN controls) NEFA response to an epinephrine challenge (Baumgard and Rhoads, 2013). These observations agree with rodent results indicating HS reduces in vivo lipolytic rates and in vitro lipolytic enzyme activity (Torlinska et al. 1987). The changes in carcass composition, blood lipid profiles and lipolytic capacity are surprising as HS causes a well-described increase in stress and catabolic hormones (epinephrine, cortisol, glucagon; Beede and Collier, 1986). These observations help to explain lipid accumulation with HS, however the underlying mechanism(s) remain to be elucidated.

During heat stress (HS) in lactating dairy cows, adipose tissue appears to become refractory to lipolytic signals whereas pair-fed cows employ mechanisms allowing lipid mobilization to spare glucose utilization in peripheral tissues. Despite this, little is known regarding the effects of $\mathrm{HS}$ on metabolic gene 
expression in adipose tissue. To evaluate the role of heat stress on lactating dairy cow adipose tissue gene expression, biopsies were obtained at the end of our typical HS and PFTN periods (Xie et al. 2012). Heat stress decreased hormone sensitive lipase (HSL), adipose triglyceride lipase (ATGL), lipoprotein lipase (LPL), peroxisome proliferator-activated receptor $\alpha$ (PPARa), and $\beta$-adrenergic receptor 2 (BAR2), but were unaltered by PFTN. The protein abundance of ATGL was increased in PFTN, but decreased in HS. Feed restriction also increased the protein abundance of BAR2 and perilipin (PLIN), while HS had no effect. These results indicate that HS directly alters adipose tissue metabolism-related gene expression independently of reduced plane of nutrition in a manner that supports the apparent lack of HS adipose tissue mobilization (Xie et al. 2012). Next, we sought to investigate the apparent refractory nature of adipose tissue to catecholamines. In an experiment designed to test adipose responsiveness to chronic epinephrine exposure, we measured abundance of adipose tissue proteins involved in epinephrine signaling (Xie et al. 2014). Adrenergic stimulation increased the phosphorylatioin ratio of cyclic-AMP response elementbinding protein (CREB) and HSL during PFTN but not during HS. Adipose triglyceride lipase protein expression was blunted by epinephrine in both PFTN and HS. Fatty acid synthase, acetyl-CoA carboxylase (ACC) and phosphorylated ACC protein abundance were decreased by HS but were not altered by epinephrine challenge (Xie et al. 2014). Taken together, these observations provide evidence that HS animals become refractory to epinephrine and limit their lipid mobilization by intrinsic changes to key proteins.

\section{Heat Stress and Skeletal Muscle Metabolism}

Metabolic adaptations to a heat load likely occur in order to increase survival probability. Lee and Scott (1916) postulated a shift in fuel supply to skeletal muscles (the primary source of metabolic heat) in an attempt to decrease metabolic heat production. Fink et al. (1975) were first to demonstrate the effect of environmental temperature on substrate utilization by skeletal muscle. This study as well as others, suggest augmented intramuscular carbohydrate use when exercising in the heat compared to cooler environments. Similarly, if the rise in body temperature was prevented or attenuated, muscle glycogenolytic rate and/or carbohydrate oxidation was reduced
(Kozlowski et al. 1985; Febbraio et al. 1994a, 1994b, 1996; Gonzalez-Alonso et al. 1999). However, increased carbohydrate utilization during exercise in hot environments may not be due to increased glucose uptake, but rather to increased intramuscular glycogen breakdown. These data suggest glycogen utilization is enhanced during exercise in a hot environment, which may be due to increased/enhanced anaerobic metabolism.

The pyruvate dehydrogenase (PDH) complex controls glucose flux through the TCA cycle and is responsible for the irreversible conversion of pyruvate to acetyl-CoA. The PDH complex is primarily regulated via covalent modification by pyruvate dehydrogenase kinases (PDKs), which inactivate $\mathrm{PDH}$, and pyruvate dehydrogenase phosphatases (PDPs), which activate PDH (Harris et al. 2002). The activity of the PDKs and PDPs are themselves regulated at the transcriptional level by intracellular energy status, metabolism intermediates (acetyl-CoA and $\mathrm{NADH}$ ), and transcription factors as well as by hormones such as cortisol and insulin (Johnson and Denton, 2003; Sugden and Holness, 2006). Cellular energy status (i.e. ATP/AMP ratio) is one of the primary mechanisms for determining substrate utilization. Inactivation the PDH complex may be a glucose-sparing mechanism, although reduced oxidative glucose metabolism during HS may instead be the result of events stemming from intracellular reactive oxygen species (ROS). In support of the literature, we consistently observe increases in bovine skeletal muscle PDK4 mRNA abundance during HS (Rhoads et al. 2008; Wheelock et al. 2008). Interestingly, numerous studies indicate plasma lactate concentrations rise during exercise in the heat (Rowell et al. 1968; Fink et al. 1975; Angus et al. 2001), porcine malignant hyperthermia (Hall et al. 1980), and heat-stressed growing steers (O'Brien et al. 2010), presumably stemming from skeletal muscle efflux. These studies point to increased anaerobic glycolysis in peripheral tissues and the Cori cycle may be a key mechanism to maintain glucose and energy homeostasis. Consistent with this notion, Rowell and coworkers (1968) reported enhanced hepatic glucose production in heat-stressed humans, an effect that could not be blunted by exogenous glucose supply (Febbraio et al. 1996, 2001; Angus et al. 2001). Hepatic pyruvate carboxylase gene expression, a ratelimiting gluconeogenic enzyme controlling lactate and alanine entry into the gluconeogenic pathway, is consistently increased during HS in ruminants (O'Brien 
et al. 2008; Wheelock et al. 2008). Taken together, increased transcription of PDK4, and the subsequent inactivation of the PDH complex might serve as a mechanism to reduce substrate oxidation and mitochondria ROS production in an effort to prevent cellular damage during HS. From a growth perspective, this strategy may limit energy necessary for anabolic processes and probably explains why efficiency is compromised in hot environments. Regardless, having a better understanding of the cellular energy equilibrium during $\mathrm{HS}$ is necessary in order to devise mitigating strategies for producers.

Previous reports suggest mitochondria may be affected directly by heat stress (Polla et al. 1996; Bornman et al. 1998; Davidson and Schiestl 2001; Heise et al. 2003; Qian et al. 2004). Histological analysis of skeletal muscle in a rat heat stroke model showed mitochondrial abnormalities, denoted as ragged-red fibers (RRFs) and electron-microscopic observations revealed an increased number and size as well as altered morphology of mitochondria (Hsu et al. 1995). Interestingly, the location of mitochondria from heat-stressed rats was also altered as skeletal muscle expressing RRFs exhibited mitochondria aggregated within the subsarcolemmal space, suggesting an increased energy demand of the plasma membrane due to hyperthermia (Hsu et al. 1995). In rat cardiomyocytes, heat stress resulted in swollen mitochondria with broken cristae and low matrix density, in addition to decreased ATP content in the myocardium (Qian et al. 2004; Song et al. 2000).

Since mitochondria are a major source of energy production within the cell, damage to mitochondria can impair a cell's ability to compensate for the increased energy demands (Hubbard, 1990) imposed by environmental stresses, and may contribute to increased levels of oxidative stress. We conducted a study aimed at understanding how hyperthermia influences the set points of several metabolic pathways within skeletal muscle during adaptation to chronic heat stress conditions using microarray analysis (Rhoads et al. 2008). Interrogation of the microarray data by pathway analysis has revealed dramatic changes in the skeletal muscle transcriptional profile relating to mitochondrial function. It appears that during heat stress bovine skeletal muscle experiences mitochondrial dysfunction and may lead to impaired cellular energy status. This may have broad implications for the reduced growth and heat intolerance seen during heat stress especially if skeletal muscle is not able to make necessary contributions to whole-body energy homeostasis. Further research is warranted to uncover the mechanisms underlying these metabolic changes observed during heat stress.

As cattle digest a ration, amino acids from the diet are metabolized to ammonia in the rumen, which is then either converted to microbial protein or absorbed into the blood stream. Circulating ammonia is quickly converted to urea by the liver, after which it can be either excreted or recycled (Van Soest, 1994; Visek, 1984). For reasons that are not yet understood, heat stress is one condition that increases circulating PUN concentrations. This phenomenon may be a consequence of increased skeletal muscle breakdown rather than protein metabolism. An indicator of muscle catabolism is 3-methyl-histidine, which is reported to increase in heat-stressed poultry, and is independent of reduced DMI (Yunianto et al. 1997). Direct effects of heat stress on muscle breakdown (3-methyl-histidine or creatine) have been reported in exercising men (Febbraio, 2001), rabbits (Marder et al. 1990) and lactating cows (Kamiya et al. 2006; Schneider et al. 1988). Other factors that may contribute are increased digestibility of the diet (due to decrease passage rate; West, 1999) and decreased blood flow to the kidneys for excretion of urea (Kenney and Musch, 2004; Lee et al. 2005).

The end result of these physiological changes that occur during heat stress is elevated PUN concentrations in heat-stressed cows irrespective of changes in diet formulation or declining DMI. The rise in PUN concentrations during periods of heat stress has been described in two separate studies where diet formulation was the same for cows in thermal-neutral and heat stress conditions. In a study conducted by Wheelock et al. (2010) the PUN concentrations of pairfed cows in thermal-neutral conditions were compared to those of heat-stressed cows and in another study conducted by Settivari et al. (2007) PUN concentrations were measured as cows transitioned from thermal-neutral to heat stress conditions. Both experimental designs resulted in significantly increased PUN concentrations during heat stress.

\section{Conclusions}

Cattle are forced to employ numerous metabolic adaptations in an attempt to maintain homeothermy during periods of heat stress. Unfortunately, many of 
these adaptations are detrimental to growth and lactation performance. It is clear that heat stress alters metabolism in multiple tissues, which may be a contributing factor to reduced animal performance. This may be particularly important if adipose tissue is unable to contribute to NEFA supply and intracellular energy demands to offset catabolic processes. In turn, an increased reliance on glucose use in peripheral tissues may interrupt nutrient partitioning strategies to limit milk production. Ongoing research is committed to elucidating the mechanisms responsible for decreased performance in the presence of metabolic alterations during heat stress. Results of these experiments will provide the knowledge we need to develop strategies for ameliorating the economic impact of heat stress on production in cattle.

Parts of this proceedings paper were adapted from the 2011 Southwest Nutrition and Management Conference in Tempe, Arizona.

\section{References}

Angus, D.J., M.A. Febbraio, D. Lasini, and M. Hargreaves. 2001. Effect of carbohydrate ingestion on glucose kinetics during exercise in the heat. Journal of Applied Physiology 90:601-605.

Bauman, D.E., C.J. Peel, W.D. Steinhour, P.J. Reynolds, H.F. Tyrrell, A.C.G. Brown, and G.L. Haaland. 1988. Effect of bovine somatotropin on metabolism of lactating dairy cows: influence on rates of irreversible loss and oxidation of glucose and nonesterified fatty acids. Journal of Nutrition 118:1031-1040.

Baumgard, L., and R. Rhoads. 2013. Effects of heat stress on postabsorptive metabolism and energetics. Annual Review of Animal Biosciences 1: 7.1-7.27.

Beede, D.K., and R.J. Collier. 1986. Potential nutritional strategies for intensively managed cattle during thermal stress. Journal of Animal Sciences 62: 543-554.

Bornman, L., C.M. Steinmann, G.S. Gericke, and S. Polla. 1998. In vivo heat shock protects rat myocardial mitochondria. Biochemical Biophysical Research Communications 246:836-840.

Brasaemle, D., L.V. Subramanian, A. Garcia, A. Marcinkiewicz, and A. Rothenberg. 2009. Perilipin A and the control of triacylglycerol metabolism. Molecular and Cellular Biochemistry 326: 15-21.
Collier, R.J., D.K. Beede, W.W. Thatcher, L.A. Israel, and C.J. Wilcox. 1982. Influences of environment and its modification on dairy animal health and production. Journal of Dairy Science 65:2213-2227.

Collier, R.J., and D.K. Beede. 1985. Thermal stress as a factor associated with nutrient requirements and interrationships. Nutrition of Grazing Ruminants in Warm Climates. L.R. McDowell (ed.). Academic Press Inc., Orlando, FL.

Collier, R., G. Dahl, and M. VanBaale. 2006. Major advances associated with environmental effects on dairy cattle Journal of Dairy Science 89:1244 - 1253.

Davidson, J.F., and R.H. Schiestl. 2001. Mitochondrial respiratory electron carriers are involved in oxidative stress during heat stress in $\mathrm{S}$. cerevisiae. Molecular Cellular Biology. 21: 8483-8489.

Duncan, R. E., M. Ahmadian, K. Jaworski, E. Sarkadi-Nagy, and H. S. Sul. 2007. Regulation of lipolysis in adipocytes. Annual review of nutrition 27: 79-101.

Elvinger, F., R. P. Natzke, and P. J. Hansen. 1992. Interactions of heat stress and bovine somatotropin affecting physiology and immunology of lactating cows. Journal of Dairy Science 75:449-462.

Farese, R.V., Jr., and T.C. Walther. 2009. Lipid droplets finally get a little R-E-S-P-E-C-T. Cell 139: 855-860.

Febbraio, M.A., R.J. Snow, M. Hargreaves, C.G. Stathis, I.K. Martin, and M.F. Carey. 1994a. Muscle metabolism during exercise and heat stress in trained men: effect of acclimation. Journal of Applied Physiology 76:589-97.

Febbraio, M.A., R.J. Snow, C.G. Stathis, M. Hargreaves, and M.F. Carey. 1994b. Effect of heat stress on muscle energy metabolism during exercise. Journal of Applied Physiology 77:2827-2831.

Febbraio, M.A., R.J. Snow, C.G. Stathis, and M. Hargreaves. 1996. Blunting the rise in body temperature reduced muscle glycogenolysis during exercise in humans. Experimental Physiology 81:685-693.

Febbraio, M.A. 2001. Alterations in energy metabolism during exercise and heat stress. Sports Medicine 31: 4759.

Fink, W., D. Costill, and P. Van Handel. 1975. Leg muscle metabolism during exercise in the heat and cold. European Journal Applied Physiology 34:183-190.

Fukao, T., G.D. Lopaschuk, and G.A. Mitchell. 2004. Pathways and control of ketone body metabolism: on the fringe of lipid biochemistry. Prostaglandins, leukotrienes, and essential fatty acids 70: 243-251.

Gonzalez-Alonso, J., J.A.L. Calbet and B. Nielsen. 1999. Metabolic and thermodynamic responses to dehydrationinduced reductions in blood flow in exercising humans. Journal of Physiology 520:577-589. 
Hall, G.M., J.N. Lucke, R. Lovell, and D. Lister. 1980. Procine malignant hyperthermia VII: hepatic metabolism. British Journal Anaesthesia 52:11-17.

Harris, R.A., M.M. Bowker-Kinley, B. Huang and P. Wu. 2002. Regulation of the activity of PDH complex. Advances Enzyme Regulation 42:249-259.

Heise, K., S. Puntamlo, H.O. Portner, and D. Abele. 2003. Production of reactive oxygen species by isolated mitochondria of the Antarctic bivalve Laternula elliptica under heat stress. Comparative Biochemistry Physiology Toxicology Pharmacology 134:79-90.

Hsu, Y.D., S.S. Chen, W.H. Lee, S.Z. Lin, M.C. Kao and W.L. Tsao. 1995. Mitochondrial alterations of skeletal muscle in a heat stress rat model. Proceedings National Science Council, ROC Part B Life Science 19(4):233239.

Hubbard, R.W. 1990. Heatstroke pathophysiology: the energy depletion model. Medicine Science Sports Exercise 22:19-28.

Johnson, S.A and R.M. Denton. 2003. Insulin stimulation of $\mathrm{PDH}$ in adipocytes involves two distinct signaling pathways. Biochemical Journal 369:351-356.

Kamiya, M., Y. Kamiya, M. Tanaka, T. Oki, Y. Nishiba and S. Shioya. 2006. Effects of high ambient temperature and restricted feed intake on urinary and plasma 3methylhistidine in lactating holstein cows. Animal Science Journal 77: 201-207.

Kenney, M. J. and T. I. Musch. 2004. Senescence alters blood flow responses to acute heat stress. American Journal Physiology Heart Circulation Physiology 286: $\mathrm{H} 1480-1485$.

Kerner, J., and C. Hoppel. 2000. Fatty acid import into mitochondria. Biochimica et biophysics acta 1486: 1-17.

Kozlowski, S., Z. Brzezinska, B. Kruk, H. Kaciuba-Uscilko, J. E. Greenleaf, and K. Nazar. 1985. Exercise hyperthermia as a factor limiting physical performance: temperature effect on muscle metabolism. Journal Applied Physiology 59:766-773.

Lee, F.S., and E.L. Scott. 1916. The action of temperature and humidity on the working power of muscles and on the sugar of the blood. American Journal Physiology 40:486-501.

Lee, I. Y., C. C. Lee, C. K. Chang, C. H. Chien, and M. T. Lin. 2005. Sheng mai san, a chinese herbal medicine, protects against renal ischaemic injury during heat stroke in the rat. Clinical Experimental Pharmacology Physiology 32: 742-748.

Marder, J., U. Eylath, E. Moskovitz, and R. Sharir. 1990. The effect of heat exposure on blood chemistry of the hyperthermic rabbit. Comparative Biochemistry Physiology A 97: 245-247.
McGuire, M.A., D.K. Beede, M.A. DeLorenzo, C.J. Wilcox, G.B. Huntington, C. K. Reynolds, and R. J. Collier. 1989. Effects of thermal stress and level of feed intake on portal plasma flow and net fluxes of metabolites in lactating Holstein cows. Journal of Animal Science 67:1050-1060.

McGuire, M.A., D.K. Beede, R.J. Collier, F.C. Buonomo, M.A. DeLorenzo, C.J. Wilcox, G.B. Huntington, and C.K. Reynolds. 1991. Effects of acute thermal stress and amount of feed intake on concentrations of somatotropin, insulin-like growth factor (IGF)-I and IGF-II, and thyroid hormones in plasma of lactating Holstein cows. Journal of Animal Science 69:2050-2056.

McGuire, M.A., Bauman, D.E., Miller, M.A. and G.F. Hartnell. 1992. Response of somatomedins (IGF-I and IGF-II) in lactating cows to variations in dietary energy and protein and treatment with recombinant n-methionyl bovine somatotropin. Journal of Nutrition 122:128-36

Nguyen, P., V. Leray, M. Diez, S. Serisier, J. Le Bloc'h, B. Siliart and H. Dumon. 2008. Liver lipid metabolism. Journal of Animal Physiology and Animal Nutrition 92: 272-283.

O'Brien, M.D., L.C. Cole, J.B. Wheelock, S.R. Sanders, G.C. Duff, L.H. Baumgard and R.P. Rhoads. 2008. Thermal and nutritional regulation of hepatic gluconeogenic genes in growing beef cattle. Journal of Animal Science $86: E$ Suppl 2: 455

O'Brien, M.D., R.P. Rhoads, S.R. Sanders, G.C. Duff, and L.H. Baumgard. 2010. Metabolic adaptations to heat stress in growing cattle. Domestic Animal Endocrinology 38:86-94.

Polla, B.S., S. Kantengwa, D. Francois, S. Salvioli, C. Franceschi, C. Marsac and A. Cossarizza. 1996. Mitochondria are selective targets for the protective effects of heat shock against oxidative injury. Proceedings of the National Academy of Science U.S.A. 93:6458-6463.

Prunier, A., M. Messias de Braganca, and J.L. Dividich. 1997. Influence of high ambient temperature on performance of reproductive sows. Livestock Production Science 52: 123-130.

Qian, L., X. Song, H. Ren, J. Gong. and S. Cheng. 2004. Mitochondrial mechanism of heat stress-induced injury in rat cardiomyocyte. Cell Stress Chaperones 9:281-293.

Rhoads, R.P., Kim, J.W., Leury, B.J., Baumgard, L.H., Segoale, N., Frank, S.J., Bauman, D.E. and Y.R. Boisclair. 2004. Insulin increases the abundance of growth hormone receptor in liver and adipose tissue of periparturient dairy cows. Journal of Nutrition 134:1020-7 
Rhoads, R.P., M.D. O'Brien, K. Greer, L. Cole, S. Sanders, J.B. Wheelock, and L.H. Baumgard. 2008. Consequences of heat stress on the profile of skeletal muscle gene expression in beef cattle. FASEB Journal 22:1165.1

Rhoads, M.L., R.P. Rhoads, M.J. VanBaale, R.J. Collier, S.R. Sanders, W.J. Weber, B.A. Crooker, and L.H. Baumgard. 2009. Effects of heat stress and plane of nutrition on lactating Holstein cows: I. production, metabolism, and aspects of circulating somatotropin. Journal of Dairy Science 92:1986-1997.

Rhoads, M.L., J.W. Kim, R.J. Collier, B.A. Crooker, Y.R. Boisclair, L.H. Baumgard, and R.P. Rhoads. 2010. Effects of heat stress and nutrition on lactating holstein cows: II. Aspects of hepatic growth hormone responsiveness. Journal of Dairy Science 93:170-179.

Rhoads, R.P., A.J. La Noce, J.B. Wheelock, and L.H. Baumgard. 2011. Short Communication: Alterations in expression of gluconeogenic genes during heat stress and exogenous bovine somatotropin administration Journal of Dairy Science 94:1917-21.

Rhoads, R.P., S.R. Sanders, L.H. Baumgard, and M.L. Rhoads. 2011. Metabolic Adaptations to Heat Stress with an Emphasis on Skeletal Muscle. Proceedings $26^{\text {th }}$ Annual Southwest Nutrition \& Management Conference 61-69.

Rhoads, R.P., L.H. Baumgard, J.K. Suagee, and S.R. Sanders. 2013. Nutritional interventions to alleviate the negative consequences of heat stress. Advances in Nutrition 4:267-76.

Ronchi, B., U. Bernabucci, N. Lacetera, A.V. Supplizi, and A. Nardone. 1999. Distinct and common effects of heat stress and restricted feeding on metabolic status of Holstein heifers. Zoot. Nutr. Anim. 25:11-20.

Rowell, L.B., G.L. Brengelmann, J.R. Blackmon, R.D. Twiss, and F. Kusumi. 1968. Splanchnic blood flow and metabolism in heat-stressed man. Journal of Applied Physiology 24:475-484.

Sano, H., K. Takahashi, K. Ambo and T. Tsuda. 1983. Turnover and oxidation rates of blood glucose and heat production in sheep exposed to heat. Journal of Dairy Science 66: 856-861.

Schneider, P.L., D.K. Beede, and C.J. Wilcox. 1988. Nycterohemeral patterns of acid-base status, mineral concentrations and digestive function of lactating cows in natural or chamber heat stress environments. Journal of Animal Science 66: 112-125.

Settivari, R.S., J.N. Spain, M.R. Ellersieck, J.C. Byatt, R.J. Collier and D.E. Spiers. 2007. Relationship of thermal status to productivity in heat-stressed dairy cows given recombinant bovine somatotropin. Journal of Dairy Science 90: 1265-1280.

Shwartz, G., M.L. Rhoads, M.J. VanBaale, R.P. Rhoads and L.H. Baumgard. 2009. Effects of a supplemental yeast culture on heat-stressed lactating Holstein cows. J. Dairy Sci. 92:935-942.
Song, X.L., L.J. Qian, and F.Z. Li. 2000. Injury of heat stress on rat cardiomyocytes. Chinese Journal of Applied Physiology 16:227-230.

St-Pierre, N.R., B. Cobanov, and G. Schnitkey. 2003. Economic losses from heat stress by US livestock industries. Journal of Dairy Science 86:E52-77.

Sugden, M.C. and M.J. Holness. 2006. Mechanisms underlying regulation of the expression and activities of the mammalian PDH kinases. Archives Physiology \& Biochemistry 112:139-149.

Torlinska, T., R. Banach, J. Paluszak, and A. GryczkaDziadecka. 1987. Hyperthermia effect on lipolytic processes in rat blood and adipose tissue. Acta Physiologica Polonica 38: 361-366.

Van Soest, P.J. 1994. Nutritional ecology of the ruminant. 2 ed. Comstock Publishing Associates.

Visek, W.J. 1984. Ammonia: Its effects on biological systems, metabolic hormones, and reproduction. Journal of Dairy Science 67: 481-498.

Wanders, R.J.A, J.P.N. Ruiter, L. Ijlst, H.R. Waterham, and S.M. Houten. 2010. The enzymology of mitochondrial fatty acid beta-oxidation and its application to follow-up analysis of positive neonatal screening results. Journal of Inherited Metabolic Disease 33: 479-494.

West, J.W. 1999. Nutritional strategies for managing the heat-stressed dairy cow. Journal of Animal Science 77 Suppl 2: 21-35.

Wheelock, J.B., A.J. La Noce, M.D. O'Brien, S.R. Sanders, R.J. Collier, L.H. Baumgard, and R.P. Rhoads. 2008. The effect of heat stress and exogenous bovine somatotropin on expression of genes associated with hepatic gluconeogenesis in lactating dairy cows. Journal of Dairy Science 91. E-Suppl 1. 455.

Wheelock, J.B., R.P. Rhoads, M.J. VanBaale, S.R. Sanders, and L.H. Baumgard. 2010. Effects of heat stress on energetic metabolism in lactating Holstein cows. Journal of Dairy Science 93:644-55.

Xie, G., L.W. Hall, M. Nearing, L.C. Cole, J. Allen, L.H. Baumgard, D.M. Spurlock, and R.P. Rhoads. 2012. Effects of heat stress and plane of nutrition on adipose tissue metabolism-related gene expression in lactating Holstein cows. Journal of Dairy Science Vol. 95, E-Suppl. 2: M206.

Xie, G., L.W. Hall, M. Nearing, L.C. Cole, D.M. Spurlock, L.H. Baumgard, and R.P. Rhoads. 2014. Heat stress alters adipose adrenergic signaling in lactating dairy cows. Journal of Dairy Science Vol. 97, E-Suppl. 1. 712.

Yunianto, V.D., K. Hayashi, S. Kaneda, A. Ohtsuka, and Y. Tomita. 1997. Effect of environmental temperature on muscle protein turnover and heat production in tube-fed broiler chickens. British Journal of Nutrition 77: 897-909.

Received for publication on March 21, 2016. Acepted for publication on July 16, 2016. 